\title{
Marital and love attitudes as predictors of Polish young adults' relationship status
}

\author{
Katarzyna Adamczyk \\ Faculty of Psychology and Cognitive Science, Adam Mickiewicz University, Poznan, Poland
}

BACKGROUND

The purpose of this study was to longitudinally examine the predictive role of marital and love attitudes and of the love-marriage connection for young adults' relationship status.

PARTICIPANTS AND PROCEDURE

The study was based on a sample of 117 Polish participants aged 20-33 who completed the Polish versions of the Love Attitudes Scale - Short Form and Marital Attitudes Scale and provided answers to the seven questions concerning love as a basis for marriage.

\section{RESULTS}

The performed analyses demonstrated that 1) single and partnered individuals reported similar levels of marital attitudes; 2) single individuals scored higher on the Eros love style than partnered individuals in the first assessment; 3) single individuals scored lower on the Mania love style than partnered individuals in the first and the second assessments; 4) single individuals scored higher in the first assessment on the Importance of love for entering marriage in comparison to partnered individuals. A binary logistic regression indicated that the Eros and Mania love styles in the first assessment were significant predictors of young adults' relationships in the second assessment. The alternative model predicting marital and love attitudes and the love-marriage connection at Time 2 (T2) from young adults' relationship status at Time 1 (T1) demonstrated that relationship status at $\mathrm{T} 1$ was predictive only of the Mania love style at T2.

\section{CONCLUSIONS}

The Eros and Mania love styles were significant predictors of young adults' relationships after a 12-month interval, and relationship status was predictive of the Mania love style at 12 months after the first assessment.

\section{KEY WORDS}

love attitudes; marital attitudes; non-marital relationships; relationship status; young adults

Corresponding author - Katarzyna Adamczyk, Ph.D., Faculty of Psychology and Cognitive Science, Adam Mickiewicz University, 89 AB Szamarzewskiego Str., 60-568 Poznan, Poland, e-mail: Katarzyna.Adamczyk@amu.edu.pl Authors' contribution - A: Study design · B: Data collection · C: Statistical analysis · D: Data interpretation ·

E: Manuscript preparation · F: Literature search · G: Funds collection

TO CITE THIS ARTICLE - Katarzyna Adamczyk, K. (2019). Marital and love attitudes as predictors of Polish young adults'

relationship status. Current Issues in Personality Psychology, 7(4), 298-312.

RECEIVED 20.10.2019 • REVIEWED 05.11.2019 • ACCEPTED 02.12.2019 • PUBLISHED 30.12.2019 


\section{BACKGROUND}

One of the normative human experiences involves a desire for intimate relationships and concern about one's relationship status (e.g., Spielmann et al., 2013). The issues related to romantic relationships and relationship status (i.e., having vs. not having a partner; see Lehmann et al., 2015) are of particular importance and become major goals in important life decisions for emerging and young adults (e.g., Rydz, 2011). In turn, among various types of intimate relationships and community groups, it is marriage and family that have been the most important groups of social participation over the centuries (Żurek, 2008). At the same time, changes in the domain of marital and family life in Poland demonstrate that contemporary Poles have a more positive attitude towards diverse relational structures and they are more willing to end unhappy marriages through a divorce (Fitzpatrick et al., 2013). Moreover, today marriage is more commonly perceived in terms of the fulfillment of one's psychological needs and expectations rather than as an institution fulfilling its societal functions (Fitzpatrick et al., 2013). Furthermore, it is love that is one of the most often reported reasons for getting married (e.g., Bakiera, 2009; Dion \& Dion, 1991), and the most frequently indicated source of happiness among adults (Bakiera, 2009).

Regarding the importance of intimate relationships and the relationship status issues in the period of young adulthood, as well as the role of love for human health and survival (Kapusta et al., 2018), the present study was intended to reveal the possible correlates of relationship status among Polish young adults. Since prior studies demonstrated that marital attitudes may have important consequences for behaviors, decisions, and trajectories through young adulthood (Willoughby, 2014) and that attitudes toward marriage held by young adults may be considered to be indicators of their prospective decisions in the domain of family life (Bakiera, 2009), the current investigation focused on the link between marital and love attitudes and young adults' relationship status. Therefore, the present study can be seen as part of a larger body of research seeking to cast light on how young and unmarried people's attitudes, values, and beliefs concerning marital transitions and relationships may change individual and relational behaviors (Willoughby, Hall, \& Luczak, 2013). Moreover, since the number of single persons has been on the rise (e.g., Ochnik \& Mandal, 2016), investigating factors contributing to the development of stable, satisfying romantic and marital relationships in young adulthood has theoretical and practical importance for family, developmental, and sociological scholars studying relationships and marriage, as well as for family policy experts.

\section{MARITAL ATTITUDES}

Marital attitudes refer to a person's subjective opinion of the institution of heterosexual marriage (Braaten \& Rosén, 1998). As Willoughby (2014) noted, there is a deficit of research focusing on the issue of the influence of one's marital attitudes on actual family formation. A similar deficit has also been observed in Poland. However, in one of the prior studies, Clarkberg, Stolzenberg, and Waite (1995) found that higher importance attached to marriage by young adults increases the likelihood of their transition into marriage or cohabitation and lowers the probability that the transition will be to a cohabiting union. Carroll and colleagues (2007) found that higher levels of general marital importance and priority of marriage during emerging adulthood were negatively associated with emerging adults' family formation values such as endorsement of non-marital cohabitation, out-of-wedlock childbirth, and spousal independence. Furthermore, in a study by Willoughby (2014), lower expected age of marriage and placing more importance on marriage at the end of adolescence were found to be associated with an increased likelihood of transitioning to marriage earlier than other young adults.

Prior research also indicated that marital attitudes are predictive of later marital behavior. For example, spouses who did not believe that marriage should last forever were less likely to pool their money and were more likely to have extramarital affairs (Hall, 2006). Marital attitudes may be therefore considered as key mechanisms for predicting actual marital and couple formation behaviors (Bakiera, 2009; Glenn \& Kramer, 1987; Hall, 2006; Willoughby, 2014). At the same time, although some prior empirical studies linked early marital attitudes to union formation in young adulthood, there exist two studies directly on the issue of the connection between relationship status and marital attitudes. To be precise, in a study Willoughby, Medaris, James, and Bartholomew (2015) found that negative relationship experiences or a lack of related experience (e.g., breaking up, remaining single) were associated with a decrease in marital salience over time, whereas remaining single was associated with increased expected marital timing. Furthermore, a Polish study (Adamczyk \& Hall, 2014) conducted on a sample of Polish young adults showed that, in comparison to single individuals, partnered individuals perceived marriage as the highest expression of love and intimacy and the most satisfying type of relationship to a higher degree than single individuals. Partnered individuals also perceived marriage as a relationship perfectly fit for soul mates or believed that a good marriage is inherently full of agreement and spontaneity, and they perceived marriage as being compatible with (or even promoting) maintaining clear individual identities. 


\section{LOVE ATTITUDES}

One of the most prominent taxonomies of love was proposed by Lee (1973) and further developed by Hendrick and Hendrick (1986). Lee (1973) identified three primary styles of love, i.e. Eros (romantic, passionate love), Ludus (game-playing love), and Storge (friendship love), and three main secondary styles, i.e. Mania (possessive, dependent love), Pragma (logical love), and Agape (all-giving, selfless love). At the same time, as Lee (1973) suggested, individual and relational differences in the meaning of love may affect how people conduct and construe their romantic relationships (Levine, Strzyzewski-Aune, $\&$ Park, 2006). Therefore, love styles are highly relevant to romantic relationships (Levine et al., 2006). Love attitudes are related to a diversity of outcomes, including life satisfaction, commitment, well-being, decisions to enter into marriage (Acevedo \& Aron, 2009), behaviors and feelings associated with initiation, maintenance, and dissolution of romantic relationships (Hammock \& Richardson, 2011), sex, self-esteem, personality, preferences for sexual styles, relationship qualities, and relational stability (Levine et al., 2006), and negative relational maintenance behaviors (Goodboy, Myers, \& Members of Investigating Communication, 2010). Moreover, in a recent study by Mandal and Latusek (2018), love styles were found to be related to the discrepancies between people who tend to abandon their partners in close relationships and people who are involved in long-term relationships. The authors concluded that love attitudes, especially Pragma and Ludus (and also psychological femininity and masculinity), may be of particular importance for the durability of a close relationship (Mandal \& Latusek, 2018).

Love (romantic love in particular) is one of the most often reported reasons for getting married (Bakiera, 2009; Dion \& Dion, 1991), and in Western culture and North America, romantic love is perceived as an important part of marriage (Acevedo \& Aron, 2009). Therefore, it seems reasonable to also investigate love attitudes alongside marital attitudes, as love and marriage are usually linked by people in their relational experiences. For example, in Kephart's (1967) study conducted on a US sample of college students, men to a higher degree than women expressed disagreement with the statement that they would marry a person without being in love with them. At the same time, it is important to note that alongside the belief that love is necessary for entering into marriage, another widespread belief is that love is necessary to maintain marriage (Sprecher \& Toro-Morn, 2002). In a cross-cultural study by Sprecher and Toro-Morn (2002), individuals less strongly believed that love is important for maintaining marriage than they believed that love is important for entering into marriage. At the same time, participants in Sprecher and Toro-Morn's (2002) study were not likely to believe that passionate love is necessary for maintaining the marriage.

\section{THE PRESENT STUDY}

Recognizing significant merits of prior studies, the present study expands them by focusing on marital and love attitudes, and the love-marriage connection in young adulthood as predictors of relationship status. In other words, the current investigation was intended to determine how marital and love attitudes, and the love-marriage connection, are related to relationship status (i.e., having vs. not having a partner) in young adulthood. The focus on relationship status is a result of the following observations. Firstly, non-marital romantic relationships play a crucial role in young adults' lives, their identity, self-concept, and psychological well-being (Simon \& Barrett, 2010), and contemporary young adults tend to postpone their decision to marry (Willoughby et al., 2013). Secondly, regardless of whether a given non-marital relationship results in marriage, the necessary condition for a potential marriage is the fact of having a partner. Therefore, having a partner could be considered a necessary step towards a potential marriage in line with the emerging adults' view of readiness for marriage as a process of developing interpersonal competencies, making life-long commitments to others, and developing capacities to care for others (Carroll et al., 2009). Moreover, as noted by Willoughby and colleagues (2013), all decisions made by people regarding their education, career, choice of a dating partner, and gaining experience in the domain of relationships put them (or not) on a trajectory to a possible eventual marriage.

In the domain of marital attitudes, prior research allowed for the formulation of the following specific hypotheses:

H1. Individuals having a partner will hold more positive attitudes toward marriage than single individuals.

H2. Marital attitudes at Time 1 (T1) will predict young adults' relationship status at Time 2 (T2).

In turn, although multiple studies have examined love attitudes, to date scant research has been conducted to examine whether and how love styles and the love-marriage connection are associated with relationship status in young adulthood. Therefore, no specific hypotheses were formulated regarding the issue of the connection between love attitudes and the love-marriage connection and young adults' relationship status. Instead, the purpose of the present study was to fully explore how love attitudes and the love-marriage connection are related to relationship status in young adulthood. In this 
study, the following two research questions were addressed:

RQ1. Do single young adults and young adults in non-marital relationships differ regarding love attitudes and the love-marriage connection?

RQ2. Can love attitudes and the love-marriage connection at $\mathrm{T} 1$ be predictive of young adults' relationship status at T2?

In addition, to verify the predictive role of marital and love attitudes and the love-marriage connection for relationship status, an alternative model predicting marital and love attitudes and the love-marriage connection at $\mathrm{T} 2$ from the relationship status at $\mathrm{T} 1$ was also intended to be tested. In line with this aim, it was hypothesized that:

H3. Relationship status at T1 will be predictive of marital attitudes at T2.

H4. Relationship status at T1 will be predictive of love attitudes at $\mathrm{T} 2$.

H5. Relationship status at T1 will be predictive of the love-marriage connection at $\mathrm{T} 2$.

\section{PARTICIPANTS AND PROCEDURE}

In the present study, the inclusion criteria were as follows: 1) being 20-40 years of age (defined as the young adulthood period), 2) being heterosexual, 3) having no children, and 4) having single status or partnered status (i.e., being in a non-marital relationship). Being single was defined as "not in a committed relationship for at least 6 or more months, but wanting to become committed in the near future (within the next year or so)" (see Donnelly \& Burgess, 2008; Schachner, Shaver, \& Gillath, 2008). In turn, partnered status was defined as "in a committed relationship for at least 6 or more months, and wanting to be committed in the near future (within the next year or so)" (see Donnelly \& Burgess, 2008; Schachner et al., 2008). The criterion of six months was used to distinguish between single and partnered status based on a prior study by Donnelly and Burgess (2008). Regarding this criterion, all participants who were single or in a non-marital romantic relationship for a period shorter than six months were excluded from further analysis.

The first assessment of variables took place in the period between May and October 2013, and the second assessment took place after a one-year interval, that is, in the period between May and October 2014. The one-year interval between the two assessments was used in the present study since any behaviors and decisions in the domain of romantic relationships require a longer period to appear. Therefore, such a long time frame was expected to increase the possibility of any changes happening regarding relationship status. Originally, 1,200 questionnaires were distributed. A total of 546 participants returned completed questionnaires (response rate $=45.50 \%$ ) Of them, 152 participants were excluded from further analyses due to incomplete data $(n=23)$, being married, widowed, divorced, separated, or because their partnered or single status was shorter than the arbitrary criterion of being in a relationship or being single for at least 6 months $(n=116)$. This yielded a sample of 394 participants, of whom 124 participants $(31.47 \%)$ initially agreed to participate in the second assessment after a one-year interval. Of 24 participants who initially agreed to participate in the second assessment, four respondents refused to participate in the second assessment, and three participants changed their single status to partnered status. Since only three individuals changed their single status to partnered status, they were excluded from further analyses so that only data gathered from participants of the same relationship status in both assessments were analyzed. As a result, the final analyses were performed on a sample of 117 participants. In addition, the analyses revealed that single individuals more often declined to participate in the second assessment than individuals in a relationship (an increase from $41.20 \%$ in the first assessment to $28.20 \%$ in the second assessment). (All details concerning the comparisons regarding demographic and psychological variables between individuals who participated only in the first assessment and individuals who participated in both assessments are available upon e-mail request.)

The demographic characteristics of participants who participated in both assessments are presented in Table 1.

The author distributed the measures to students across different courses with the request to administer the questionnaires to their relatives, friends, and acquaintances. The questionnaire packages were administered in classrooms to groups of 20 to 30 students at a time, and participation was voluntary. An explanation of the study's purpose was given along with an assurance that all information provided would remain confidential. Students who volunteered to participate received extra credit toward their final course grade. The study was positively evaluated by the Human Research Ethics Committee affiliated with the Institute of Psychology at Adam Mickiewicz University in Poznan.

\section{MATERIALS}

The questionnaire package presented to the study participants comprised the following instruments:

Demographic Questionnaire. This questionnaire was designed to obtain general descriptive information about participants' background characteristics such as age, gender, education, and current relationship status. 
Table 1

General demographic data of participants $(N=117)$

\begin{tabular}{|c|c|c|}
\hline Variable & $\begin{array}{c}1^{\text {st }} \\
\text { assessment }\end{array}$ & $\begin{array}{c}2^{\text {nd }} \\
\text { assessment }\end{array}$ \\
\hline \multicolumn{3}{|l|}{ Age (20-33 years) } \\
\hline$M(S D)$ & $21.42(1.79)$ & $22.23(1.77)$ \\
\hline \multicolumn{3}{|l|}{ Sex } \\
\hline Females & $94(80.30 \%)$ & $94(80.30 \%)$ \\
\hline Males & $23(19.70 \%)$ & $23(19.70 \%)$ \\
\hline \multicolumn{3}{|l|}{ Relationship status } \\
\hline Single individuals & $36(30.80 \%)$ & $36(30.80 \%)$ \\
\hline $\begin{array}{l}\text { Individuals in } \\
\text { relationships }\end{array}$ & $81(69.20 \%)$ & $81(69.20 \%)$ \\
\hline \multicolumn{3}{|l|}{$\begin{array}{l}\text { Duration of being } \\
\text { single in years }\end{array}$} \\
\hline$M(S D)$ & $6.06(8.57)$ & $7.35(10.00)$ \\
\hline \multicolumn{3}{|l|}{$\begin{array}{l}\text { Duration of being in } \\
\text { a relationship in years }\end{array}$} \\
\hline$M(S D)$ & $2.51(1.69)$ & $2.87(1.98)$ \\
\hline \multicolumn{3}{|l|}{ Educational level } \\
\hline Student & $113(96.60 \%)$ & $84(71.80 \%)$ \\
\hline Non-student & $4(3.40 \%)$ & $33(28.20 \%)$ \\
\hline
\end{tabular}

Love Attitudes Scale - Short Form (LAS; Hendrick, Hendrick, \& Dicke, 1998; Polish adaptation - Adamczyk, 2019). The Love Attitudes Scale - Short Form is a shortened version of the original 42-item Love Attitudes Scale (Hendrick \& Hendrick, 1986). It consists of 24 items, constituting six different subscales that represent six different love styles as distinguished by Lee (1973): Eros, Ludus, Storge, Pragma, Mania, and Agape. Respondents were asked to respond to each item using a 5-point scale, ranging from 1 (strongly agree) to 5 (strongly disagree). Sample items are as follows: "My partner and I have the right physical 'chemistry' between us", "Our love is the best kind because it grew out of a long friendship", and "One consideration in choosing my partner was how he/she would reflect on my career." The internal consistency for the subscales in the original study by Hendrick was as follows: $\alpha=.82, \alpha=.68, \alpha=.84, \alpha=.77, \alpha=.69$, $\alpha=.85$, for Eros, Ludus, Storge, Pragma, Mania, and Agape respectively. In the present study, in the first assessment the internal consistency for the subscales was as follows: $\alpha=.81, \alpha=.34, \alpha=.86, \alpha=.66, \alpha=.66$, $\alpha=.80$, for Eros, Ludus, Storge, Pragma, Mania, and Agape respectively. In the second assessment, the internal consistency for the subscales was as follows: $\alpha=.76, \alpha=.30, \alpha=.82, \alpha=.72, \alpha=.61, \alpha=.82$, for Eros, Ludus, Storge, Pragma, Mania, and Agape respectively. Considering that the coefficient $\alpha$ in the first and the second assessment was below .50 for the Ludus scale in the studied sample, no analyses were conducted for this scale. The low reliability of the Ludus scale was also determined in prior research. For instance, in their study of a Chinese sample, Sprecher and Toro-Morn (2002) found the coefficient $\alpha$ to be below .50 for both the Eros and Ludus scales. Similarly, also another study determined the low Cronbach $\alpha$ coefficient (.57) for the Ludus scale (Shurts \& Myers, 2008). In turn, the test-retest reliability of the subscales was as follows: Eros, $r=.39, p<.001$ (twotailed); Storge, $r=.46, p<.001$ (two-tailed); Pragma, $r=.58, p<.001$ (two-tailed); Mania, $r=.56, p<.001$ (two-tailed); and Agape, $r=.64, p<.001$ (two-tailed). Marital Attitudes Scale (MAS; Braaten \& Rosén, 1998; Polish adaptation - Adamczyk, 2019). The MAS is a self-report measure designed to assess the global perception of heterosexual marriage. Participants are asked how strongly they agree or disagree with 23 statements regarding marriage - from 0 (strongly agree) to 3 (strongly disagree). Sample items are as follows: "1 have little confidence that my marriage will be a success" and "I have doubts about marriage." Six of the items refer to feelings regarding participants' present, or possibly future, marriage, while the remaining items require the participants to react to statements concerning general concepts regarding marriage. The MAS is calculated by adding up individual items' scores. The total MAS score can range from a minimum of 23 to a maximum of 92 . Higher scores indicate a more positive attitude toward marriage. The MAS has been shown to have favorable psychometric properties with high internal consistency, $\alpha=.82$ (Braaten \& Rosén, 1998). In the present study, in the first assessment, the internal consistency for the total scale was $\alpha=.87$. In the second assessment, the internal consistency for the total scale was $\alpha=.67$. In addition, the test-retest reliability of the scale was $r=.47, p<.001$ (two-tailed).

Love as a basis for marriage. Following studies by Kephart (1967), Simpson, Campbell, and Berscheid (1986), and Sprecher and Toro-Morn (2002), the present study included questions concerning love as a basis for marriage. These questions were as follows: 1) "If a man (woman) had all other qualities you desire, would you marry this person if you were not in love with him (her)?" (Kephart, 1967); 2) "If a man (woman) had all the other qualities you desire and you experienced friendship/companionate love but not sexual attraction or passionate love for him (her), would you marry him (her)?” (Sprecher \& Toro-Morn, 2002); 3) "If love has completely disappeared from a marriage, I think it is probably best for the couple to make a clean break and start new lives" (Simpson et al., 1986); 4) "In my opinion, the 
disappearance of love is not a sufficient reason for ending a marriage, and should not be viewed as such" (Simpson et al., 1986); 5) "In your opinion, if passionate love or sexual attraction has disappeared from a marriage, but the two still love each other in a companionate/friendship way, is it probably best for the couple to make a clean break and start new lives?" (Sprecher \& Toro-Morn, 2002); 6) "How important is to you that marriage be emotionally satisfying for you to want to continue it?" (Sprecher \& Toro-Morn, 2002); and 7) "How important is to you that marriage be physically pleasurable for you to want to continue it?" (Sprecher \& Toro-Morn, 2002). In addition, the test-retest reliability of individual items was as follows: importance of love for entering into marriage, $r=.20, p=.032$ (two-tailed); importance of passionate love for entering into marriage, $r=.32, p<.001$ (twotailed); importance of love for maintaining marriage, $r=.41, p<.001$ (two-tailed); importance of passionate love for maintaining marriage, $r=.28, p=.002$ (two-tailed); importance of emotional satisfaction for maintaining marriage, $r=.41, p<.001$ (two-tailed); and importance of physical pleasure for maintaining marriage, $r=.52, p<.001$ (two-tailed).

\section{RESULTS}

\section{PRELIMINARY ANALYSES}

As a starting point, to determine stability over time in the domains of marital and love attitudes and of the love-marriage connection, a one-way repeatedmeasures ANOVA was performed (see Table 2).

As shown in Table 2, there were no differences between the first and the second assessment in the domains of marital and love attitude and the lovemarriage connection. Therefore, it can be concluded that these variables displayed stability over a oneyear interval.

\section{SUBSTANTIVE ANALYSES}

The mean-level differences in marital and love attitudes and the love-marriage connection. To determine the potential mean-level differences in the domain of marital and love attitudes, as well as in the domain of love-marriage connection, a one-way ANOVA analysis was performed (see Tables 3 and 4 ).

Table 2

Means, standard deviations, effect sizes, and significance levels for the first and second assessments. Results of a one-way repeated measures ANOVA

\begin{tabular}{|c|c|c|c|c|}
\hline Variables & $\begin{array}{c}1^{\text {st }} \text { assessment } \\
(N=117) \\
M(S D)\end{array}$ & $\begin{array}{c}2^{\text {nd }} \text { assessment } \\
(N=117) \\
M(S D)\end{array}$ & $F_{\text {ratio }}{ }^{a}$ & $\eta^{2}$ \\
\hline Marital attitudes & $34.84(4.76)$ & $35.05(6.23)$ & 0.14 & .00 \\
\hline \multicolumn{5}{|l|}{ Love attitudes } \\
\hline Eros & $6.04(2.52)$ & $6.44(2.59)$ & 2.43 & .02 \\
\hline Storge & $9.88(3.59)$ & $10.26(3.24)$ & 1.36 & .01 \\
\hline Pragma & $10.66(3.02)$ & $10.29(2.98)$ & 2.17 & .02 \\
\hline Mania & $9.08(2.92)$ & $9.47(2.58)$ & 2.68 & .02 \\
\hline Agape & $8.48(2.84)$ & $8.73(2.92)$ & 1.21 & .01 \\
\hline \multicolumn{5}{|l|}{ Love-marriage connection } \\
\hline Importance of love for entering marriage & $1.89(1.06)$ & $2.00(1.03)$ & 0.83 & .01 \\
\hline $\begin{array}{l}\text { Importance of passionate love for entering } \\
\text { marriage }\end{array}$ & $2.12(1.11)$ & $2.26(1.07)$ & 1.35 & .01 \\
\hline Importance of love for maintaining marriage & $2.98(1.28)$ & $2.93(1.22)$ & 0.17 & .00 \\
\hline $\begin{array}{l}\text { Importance of passionate love for } \\
\text { maintaining marriage }\end{array}$ & $2.22(1.18)$ & $2.35(1.17)$ & 0.97 & .00 \\
\hline $\begin{array}{l}\text { Importance of emotional satisfaction } \\
\text { for maintaining marriage }\end{array}$ & $1.39(0.62)$ & $1.43(0.63)$ & 0.30 & .00 \\
\hline $\begin{array}{l}\text { Importance of physical pleasure } \\
\text { for maintaining marriage }\end{array}$ & $2.15(0.85)$ & $2.09(0.82)$ & 0.46 & .00 \\
\hline
\end{tabular}


As demonstrated in Tables 3 and 4, no significant differences in the domain of marital attitudes between single individuals and individuals in non-marital relationships emerged in the first assessment (T1), $F(1,115)=1.83, p=.179, \eta^{2}=.02$, or in the second assessment (T2), $F(1,115)=2.10, p=.150, \eta^{2}=.02$.

In regard to love styles, the following differences were observed: 1) single individuals scored higher on the Eros love style than individuals in non-marital relationships in the first assessment (T1), $F(1,115)=10.97$, $p<.001, \eta^{2}=.09$, but this pattern of results was not replicated in the second assessment (T2), $F(1,115)=1.15$, $\left.p=.287, \eta^{2}=.01 ; 2\right)$ single individuals scored lower on the Mania love style than individuals in non-marital relationships in the first assessment $(\mathrm{T} 1), F(1,115)=4.04$, $p=.047, \eta^{2}=.03$, as well as in the second assessment (T2), $F(1,115)=5.95, p=.016, \eta^{2}=.05$.

Furthermore, regarding the love-marriage connection only one significant difference emerged in the first assessment (T1) between single individuals and individuals in non-marital relationships in the domain of the attitude termed importance of love for entering into marriage. Specifically, single individuals scored higher on importance of love for entering into marriage in comparison to individuals in non-marital relationships, $F(1,115)=4.48, p=.037, \eta^{2}=.04$. At the same time, this pattern of results was not replicated in the second assessment (T2), $F(1,115)=0.00, p=1.00$, $\eta^{2}=.00$, and single individuals reported the same level of importance of love for entering into marriage as coupled individuals (see Table 4).

Marital and love attitudes and the love-marriage connection at $T 1$ as predictors of relationship status at T2. To examine whether all marital and love attitudes analyzed in the current investigation and the love-marriage connections measured in the first assessment can be significant predictors of relationship status in the second assessment, binary logistic regression analysis with the enter method was performed. The performed analysis revealed the significance of the tested model, $\chi^{2}(12)=23.73, p=.022$. Furthermore, the tested model correctly classified $70.10 \%$

Table 3

Means and standard deviations for marital attitudes, love attitudes, and love-marriage connection in the first assessment

\begin{tabular}{|c|c|c|c|c|}
\hline \multirow[t]{3}{*}{ Variables } & \multicolumn{2}{|c|}{$1^{\text {st }}$ assessment } & \multirow[t]{3}{*}{$F$ value } & \multirow[t]{3}{*}{$\eta^{2}$} \\
\hline & $\begin{array}{l}\text { Partnered } \\
\text { individuals } \\
\quad(n=81)\end{array}$ & $\begin{array}{c}\text { Single } \\
\text { individuals } \\
(n=36)\end{array}$ & & \\
\hline & \multicolumn{2}{|c|}{$M(S D)$} & & \\
\hline Marital attitudes & $35.24(4.94)$ & $33.95(4.25)$ & 1.83 & .02 \\
\hline \multicolumn{5}{|l|}{ Love styles } \\
\hline Eros & $5.54(1.93)$ & $7.15(3.26)$ & $10.97^{* *}$ & .09 \\
\hline Storge & $9.99(3.53)$ & $9.63(3.75)$ & 0.25 & .00 \\
\hline Pragma & $10.82(3.11)$ & $10.31(2.80)$ & 0.72 & .01 \\
\hline Mania & $9.44(2.99)$ & $8.28(2.62)$ & $4.04^{*}$ & .03 \\
\hline Agape & $8.21(2.61)$ & $9.10(3.25)$ & 2.47 & .02 \\
\hline \multicolumn{5}{|l|}{ Love-marriage connection } \\
\hline Importance of love for entering marriage & $1.75(0.92)$ & $2.19(1.28)$ & $4.48^{*}$ & .04 \\
\hline $\begin{array}{l}\text { Importance of passionate love for entering } \\
\text { marriage }\end{array}$ & $2.01(1.07)$ & $2.36(1.18)$ & 2.50 & .02 \\
\hline Importance of love for maintaining marriage & $2.94(1.27)$ & $3.08(1.32)$ & 0.32 & .00 \\
\hline $\begin{array}{l}\text { Importance of passionate love } \\
\text { for maintaining marriage }\end{array}$ & $2.32(1.21)$ & $2.00(1.07)$ & 1.87 & .02 \\
\hline $\begin{array}{l}\text { Importance of emotional satisfaction } \\
\text { for maintaining marriage }\end{array}$ & $1.38(0.62)$ & $1.42(0.60)$ & 0.08 & .00 \\
\hline $\begin{array}{l}\text { Importance of physical pleasure } \\
\text { for maintaining marriage }\end{array}$ & $2.16(0.86)$ & $2.11(0.85)$ & 0.08 & .00 \\
\hline
\end{tabular}


Table 4

Means and standard deviations for marital attitudes, love attitudes, and love-marriage connection in the second assessment

\begin{tabular}{|c|c|c|c|c|}
\hline \multirow[t]{3}{*}{ Variables } & \multicolumn{2}{|c|}{$2^{\text {nd }}$ assessment } & \multirow[t]{3}{*}{$F$ value } & \multirow[t]{3}{*}{$\eta^{2}$} \\
\hline & $\begin{array}{l}\text { Partnered } \\
\text { individuals } \\
\quad(n=81)\end{array}$ & $\begin{array}{c}\text { Single } \\
\text { individuals } \\
(n=36)\end{array}$ & & \\
\hline & \multicolumn{2}{|c|}{$M(S D)$} & & \\
\hline Marital attitudes & $35.60(5.77)$ & $33.80(7.09)$ & 2.10 & .02 \\
\hline \multicolumn{5}{|l|}{ Love styles } \\
\hline Eros & $6.27(2.58)$ & $6.83(2.59)$ & 1.15 & .01 \\
\hline Storge & $10.14(3.28)$ & $10.55(3.19)$ & 0.40 & .00 \\
\hline Pragma & $10.44(3.08)$ & $9.94(2.77)$ & 0.68 & .01 \\
\hline Mania & $9.85(2.45)$ & $8.62(2.70)$ & $5.95^{*}$ & .05 \\
\hline Agape & $8.60(2.10)$ & $9.03(2.76)$ & 0.55 & .01 \\
\hline \multicolumn{5}{|l|}{ Love-marriage connection } \\
\hline Importance of love for entering marriage & $2.00(1.04)$ & $2.00(1.01)$ & 0.00 & .00 \\
\hline $\begin{array}{l}\text { Importance of passionate love for entering } \\
\text { marriage }\end{array}$ & $2.31(1.11)$ & $2.14(0.96)$ & 0.63 & .01 \\
\hline Importance of love for maintaining marriage & $2.93(1.24)$ & $2.94(1.19)$ & 0.01 & .00 \\
\hline $\begin{array}{l}\text { Importance of passionate love } \\
\text { for maintaining marriage }\end{array}$ & $2.36(1.12)$ & $2.33(1.29)$ & 0.01 & .00 \\
\hline $\begin{array}{l}\text { Importance of emotional satisfaction } \\
\text { for maintaining marriage }\end{array}$ & $1.44(0.67)$ & $1.39(0.55)$ & 0.19 & .00 \\
\hline $\begin{array}{l}\text { Importance of physical pleasure } \\
\text { for maintaining marriage }\end{array}$ & $2.14(0.86)$ & $2.00(0.72)$ & 0.68 & .01 \\
\hline
\end{tabular}

Table 5

Results of logistic regression predicting relationship status at T2 from love styles at T1

\begin{tabular}{lcccc}
\hline & B (SE) & Odds ratio & \multicolumn{2}{c}{$95 \%$ CI for odds ratio } \\
\cline { 3 - 4 } Constant & & & Lower & Upper \\
$\begin{array}{l}\text { Independent variable } \\
\text { Eros }\end{array}$ & $0.73(2.39)$ & & & 0.96 \\
Mania & $-0.24^{*}(0.10)$ & 0.79 & 0.64 & 1.43 \\
\hline
\end{tabular}

Note. $R^{2}=6.06$ (Hosmer \& Lemshow), 0.18 (Cox \& Snell), 0.26 (Nagelkerke).

Dependent variable: Relationship status $\left(0-\operatorname{single~status,~} 1\right.$ - partnered status). ${ }^{*} p<.05$.

of participants. The analysis revealed that among all variables introduced into the model, significant predictors of young adults' relationship status were the Eros and Mania love styles (see Table 5).

As shown in Table 5, the odds ratio $[\operatorname{Exp}(B)]$ for the Eros love style $(\mathrm{OR}=0.79)$ is less than 1 . Therefore, this odds ratio indicates that with the increase in scoring on the Eros love style, the odds of the outcome occurring (i.e., having a partner) decrease. In turn, the odds ratio $[\operatorname{Exp}(B)]$ for the Mania love style $(\mathrm{OR}=1.20)$ is higher than 1 . Therefore, this odds ratio indicates that with the increase in scoring on the Mania love style, the odds of the outcome occurring (i.e., having a partner) increase.

Relationship status at $\mathrm{T} 1$ as predictor of marital and love attitudes and the love-marriage connection at T2. To examine the alternative model predicting marital 
and love attitudes and the love-marriage connection at T2 from young adults' relationship status at T1, linear regression analyses with the entry method were performed separately for marital and love attitudes and for the love-marriage connection at $\mathrm{T} 2$.
As Table 6 demonstrates, relationship status at T1 was predictive only for the Mania love style at T2 $(\beta=.22)$ and explained $5 \%$ of the variance in the Mania love style. Being partnered at T1 was predictive of a higher level of the Mania love style at T2.

Table 6

Linear regression analysis predicting marital attitudes at T2, love attitudes at T2, and love-marriage connection at $T 2$ using relationship status at $T 1$

\begin{tabular}{|c|c|c|c|c|c|}
\hline Variables & B & SE & $\beta$ & $95 \% \mathrm{Cl}$ & $t$ \\
\hline \multicolumn{6}{|l|}{ Marital attitudes at T2 } \\
\hline Constant & 33.80 & 1.03 & & $31.75,35.85$ & 32.68 \\
\hline Relationship status at T1 & & & .13 & $-0.66,4.27$ & 1.45 \\
\hline$R^{2}$ & .02 & & & & \\
\hline
\end{tabular}

Eros at T2

Constant

Relationship status at T1

$R^{2}$

Storge at T2

Constant

Relationship status at T1

$R^{2}$

Pragma at T2

Constant

Relationship status at T1

$R^{2}$

Mania at T2

Constant

Relationship status at T1

$R^{2}$

Agape at T2

Constant

Relationship status at T1

$R^{2}$

$\begin{array}{lllll}6.83 & 0.43 & & 5.97,7.68 & 15.84 \\ & & -.09 & -1.58,0.47 & -1.07 \\ .01 & & & & \end{array}$

$\begin{array}{ccccc}10.55 & 0.54 & & 9.48,11.62 & 19.47 \\ -0.41 & 0.65 & -.06 & -1.70,0.88 & -0.63 \\ .00 & & & & \end{array}$

$\begin{array}{lllll}9.94 & 0.50 & .08 & 8.96,10.93 & 19.98 \\ & & & -0.69,1.68 & 0.83 \\ .01 & & & & \end{array}$

$\begin{array}{ccccc}8.62 & 0.42 & & 7.78,9.45 & 20.43 \\ 1.24 & 0.51 & .22^{*} & 0.23,2.24 & 2.44 \\ .05 & & & & \end{array}$

$\begin{array}{ccccc}9.04 & 0.49 & & 8.07,10.00 & 18.51 \\ -0.44 & 0.59 & -.07 & -1.60,0.73 & -0.74 \\ .01 & & & & \end{array}$

Importance of love for entering marriage 1

Constant

2.00

0.17

$-1.60,0.73 \quad 11.65$

Relationship status at T1

$R^{2}$

0.00

0.21

1.66, $2.34 \quad 0.00$

.00

Importance of passionate love for entering marriage 2

Constant

Relationship status at T1

$R^{2}$

$\begin{array}{ccccc}2.14 & 0.18 & & 1.79,2.49 & 11.99 \\ 0.17 & 0.21 & .07 & -0.26,0.59 & 0.79 \\ .01 & & & & \end{array}$

(Table 6 continues) 
Table 6

(Table 6 continued)

\begin{tabular}{|c|c|c|c|c|c|}
\hline Variables & $\mathrm{B}$ & SE & $\beta$ & $95 \% \mathrm{Cl}$ & $t$ \\
\hline \multicolumn{6}{|c|}{ Importance of love for maintaining marriage 3} \\
\hline Constant & 2.94 & 0.21 & & $2.54,3.36$ & 14.39 \\
\hline Relationship status at T1 & -0.02 & 0.25 & -.01 & $-0.51,0.47$ & -0.08 \\
\hline \multicolumn{6}{|l|}{$R^{2}$} \\
\hline \multicolumn{6}{|c|}{ Importance of passionate love for maintaining marriage 4} \\
\hline Constant & 2.33 & 0.20 & & $1.95,2.72$ & 11.92 \\
\hline Relationship status at T1 & 0.03 & 0.24 & .01 & $-0.44,0.49$ & 0.11 \\
\hline \multicolumn{6}{|l|}{$R^{2}$} \\
\hline \multicolumn{6}{|c|}{$\begin{array}{l}\text { Importance of emotional satisfaction for maintaining } \\
\text { marriage } 5\end{array}$} \\
\hline Constant & 1.39 & 0.11 & & $1.18,1.60$ & 13.10 \\
\hline Relationship status at T1 & 0.06 & 0.13 & .04 & $-0.20,0.31$ & 0.44 \\
\hline \multicolumn{6}{|l|}{$R^{2}$} \\
\hline \multicolumn{6}{|c|}{ Importance of physical pleasure for maintaining marriage } \\
\hline Constant & 2.00 & 0.14 & & $1.73,2.27$ & 14.62 \\
\hline Relationship status at T1 & 0.14 & 0.16 & .08 & $-0.19,0.46$ & 0.83 \\
\hline$R^{2}$ & .01 & & & & \\
\hline
\end{tabular}

Note. 1 = partnered status, $0=$ single status; ${ }^{*} p<.05$.

\section{DISCUSSION}

The present investigation aimed to determine the predictive role of marital and love attitudes and of the love-marriage connection for Polish young adults' relationship status. Based on prior research, it was hypothesized that individuals having a partner would hold more positive attitudes toward marriage than single individuals $(\mathrm{H} 1)$ and that marital attitudes at Time 1 would predict young adults' relationship status at Time $2(\mathrm{H} 2)$. Contrary to the expectations, the above-formulated hypotheses were not confirmed by the obtained results. With respect to marital attitudes, the study demonstrated that single young adults and young adults in non-marital relationships do not differ from each other. Prior research (e.g., Sassler \& Schoen, 1999) indicated that individuals expressing positive attitudes about marriage are significantly more likely to marry. Similarly, Willoughby and colleagues (2015) found that negative relationship experiences or a lack of relationship experience (e.g., breaking up, remaining single) were related to a decrease in marital salience over time. Therefore, in the present study, it was expected that young adults who express positive attitudes toward marriage would be more likely to be in a relationship that might eventually and potentially lead to marriage. As a result, one might expect that single individuals would hold more negative attitudes toward marriage than individuals in committed relationships and that these negative attitudes would contribute to maintaining a single status. This expectation could come from the negative stereotyping of singles in the United States and Poland, which involves perceiving singles as inflexible, stubborn, flirtatious, looking for a partner, independent in comparison to married individuals (DePaulo \& Morris, 2005), willing to give up starting a family in favor of a professional career, and attaching value mostly to freedom, independence and self-decision making (Czernecka, 2008). These traits, often associated with single people, might lead to the conviction that single people may hold a negative view of marriage, and, as a result, may not be willing to become involved in serious relationships which could potentially culminate in a marriage. The results of this study, however, showed that single young adults and young adults in a non-marital relationship perceived marriage in a similar way. When attempting to explain these findings, it might be postulated that the lack of a partner and holding positive attitudes toward marriage are not mutually exclusive. It may be related to the notion that for some 
people remaining single is merely a certain phase in life before getting married or becoming committed to a serious relationship (Kaiser \& Kashy, 2005). Thus, single individuals may perceive their singlehood as a temporary state eventually leading to marriage (Palus, 2010). Furthermore, in a study by Fowers, Lyons, Montel, and Shaked (2001), which concerned positive illusions about marriage, single and married individuals had a very similar level of positive illusions concerning both their underestimates of divorce likelihood and their unrealistic confidence in having an exceptional marriage. In addition, as Fowers and colleagues (2001) suggested, positive marital illusions among single individuals may indicate that overestimates of marital success are a broader phenomenon than marriage itself. Therefore, marital attitudes as positive marital illusions may linger, although in Poland, as in many societies around the world, singlehood is becoming more common among young adults, as they wait longer before they marry and fewer people get married compared to the past times (e.g., Such-Pyrgiel, 2014).

With respect to love attitudes and the love-marriage connection in the present study, two open research questions were formulated. The first research question concerned the possible differences between single young adults and young adults in non-marital relationships regarding love attitudes and the lovemarriage connection. The second research question was related to the predictive role of love attitudes and the love-marriage connection as measured in the first assessment for young adults' relationship status after a one-year interval.

The performed analyses showed two significant differences between single and partnered individuals in the domain of the Eros love style in the first assessment, and in the domain of the Mania love style in the first and second assessments. Specifically, in the first assessment, single young adults were found to be more erotic than young adults in non-marital relationships, whereas young adults in non-marital relationships were more manic than single young adults. When attempting to explain this pattern of results, it may be pointed out that one of the traits of the Eros love style is the belief in "love at first sight" and the desire for intimacy from the very beginning of a relationship (Hahn \& Blass, 1997). It can be assumed that this type of love style may be characteristic of single individuals as they are not in committed relationships and - at the same time - they desire such relationships. This desire may, in turn, make single people particularly prone to fall instantly and completely in love with a stranger (i.e., to experience "love at first sight"), and be rapidly preoccupied with pleasant thoughts about the potential partner (Regan, 2008). In addition, these traits correspond to romantic beliefs of, for example, "love at first sight" (i.e., belief that true love can happen without prior interaction). In turn, idealized romantic beliefs that presume effortless relationship formation and perfection of the partner as well as of the relationship are considered to be unrealistic standards of marital relationships (Medora, Larson, Hortaçsu, \& Dave, 2002). High levels of romantic ideals may lead to negative consequences (Murray \& Holmes, 1997), such as disappointment with the relationship, marital conflict, or even divorce (Baucom \& Epstein, 1990). Therefore, in the light of the obtained results, we may state that erotic attitudes to love are associated with single status in young adulthood.

Regarding the Mania love style, we can indicate that it is an obsessive and jealous love which makes individuals desperate to fall in love and to be loved, wanting to see the partner daily, forcing the partner to show love and commitment, and distrusting the partner's sincerity (Regan, 2008). Manic individuals, for instance, like to spend plenty of time with their partners, and they tend to fear that they will give too much to their partners without being reciprocated (Hahn \& Blass, 1997). The traits listed above seem to be specific to individuals in committed, quite wellestablished relationships in which partners value such aspects of their relationship as intimacy, sharing common activities and interests, or the desire that the relationship will work well. If so, it is not surprising that individuals in non-marital relationships scored significantly higher on the Mania love style than single individuals, as the present study demonstrated.

With respect to the issue of the love-marriage connection, the results of the present study revealed only one significant difference in the first assessment between single individuals and individuals in nonmarital relationships. Specifically, single individuals to a higher degree were more willing to hold the conviction that love is important for entering into a marriage in comparison to individuals in non-marital relationships. This pattern of results may be understood in reference, for instance, to romantic beliefs (Medora et al., 2002), and reflect an idealistic view of marriage held by single individuals that has not yet been verified by their experiences of being in a relationship. In turn, individuals who have a partner may have different experiences than single individuals, and they have other reasons than just love for being in a given relationship.

Finally, and most importantly, the present study also demonstrated the predictive role of the Eros and Mania love styles for young adults' relationship status. To be precise, a higher level of the Eros love style and a lower level of the Mania love style contribute to single status. In other words, the more erotic and the less manic the individuals are, the more probable they are to remain single. Once again we can conclude that traits associated with the Eros and Mania love styles may, at least in the case of the present 
study, prevent individuals from forming a romantic relationship. In turn, in prior studies, Hendrick and Hendrick (2002) found that individuals who were not currently in a romantic relationship preferred the Ludus love style. As Mandal and Latusek (2018) suggested, it is reasonable to assume that individuals who prefer the game-playing love type simply do not desire to marry. This association between the Eros and Mania love styles and relationship status is consistent with the observation that beliefs about romantic relationships have important implications for relational initiation, maintenance, and termination, and that individuals' beliefs about love influence the approach to and performance of their romantic encounters and relationships (Levine et al., 2006). As Medora and colleagues (2002) explained, the complexity of idealized romantic beliefs lies in the fact that they can serve an important function in relationships when they buffer the effects of negative events and facilitate resilience. On the other hand, romantic beliefs that entail the assumptions that relationships are formed and maintained with little effort because one's partner and the relationship will be perfect are unrealistic and likely to lead to disappointment with the partner and dissatisfaction with the relationship.

Furthermore, to verify the predictive role of marital and love attitudes and of the love-marriage connection at $\mathrm{T} 1$ for relationship status at $\mathrm{T} 2$, an alternative model predicting marital and love attitudes, and the love-marriage connection at T2 from relationship status at T1 was investigated. The linear regression analyses performed separately for marital attitudes, six love styles, and six love-marriage connections revealed that relationship status at T1 predicted only the level of the Mania love style at T2. In regard to all other variables, relationship status at T1 was not a significant predictor. The pattern of the majority of non-significant associations between relationship status at T1 and marital and love attitudes, and the love-marriage connection seems to support the claim that the Eros love style and the importance of love for entering into marriage are predictive of the relationship status at $\mathrm{T} 2$ rather than the relationship status at $\mathrm{T} 2$ being predictive of marital and love attitudes (except for the Mania love style), and the love-marriage connection.

Although this investigation was exploratory, there are several limitations of the present study. Firstly, the sample used in the present study was small and consisted mainly of partnered individuals. Therefore, larger samples are needed to provide stronger evidence for the relationships revealed in the present study. In future research, it would also be beneficial to determine the measurement invariance of love and marital attitudes across single and partnered individuals, i.e., to determine whether the research tools used to measure the same constructs among these two groups, as it was determined in regard to gender. Specifically, Cramer, Marcus, Pomerleau, and Gillard (2015) demonstrated that the subscales of the 42-item Love Attitudes Scale (Hendrick \& Hendrick, 1986) are invariant across genders, and therefore any gender comparisons regarding the love subscales should be performed with caution (Cramer et al., 2015). Secondly, the sample used in the present study represents a specific developmental stage, as it consisted of young adults who had never married and were childless and heterosexual. In future studies, it would be useful to compare, for instance, individuals of different relationship history, expanding the single and partner status category to include also divorced, separated, and widowed individuals. The study group consisted mainly of students who are going through the period of emerging and young adulthood. It is the time when young people postpone their decisions to form a relatively stable relationship, start a family, give birth to their first and next child, and leave their family home (Borchet, Lewandowska-Walter, \& Rostowska, 2018; Brzezińska, Kaczan, Piotrowski, \& Rękosiewicz, 2011), and "this population of emerging adults has shown that they gradually achieve important developmental markers for adulthood (...)" (Barry, Madsen, Nelson, Carroll, \& Badger, 2009, p. 220). Moreover, our sample was predominated by women, and - as prior studies demonstrated - gender differences do exist in the domain of love styles (Mandal \& Latusek, 2018), with women perceiving love as Mania or Pragma (Hendrick \& Hendrick, 1995). Therefore, the predominance of women in our sample might have affected the results obtained. Thirdly, although the present study provides a better insight into the causal link between marital and love attitudes, and the love-marriage connection, it does not investigate mechanisms underlying this link. Therefore, in future studies, it would be useful to include also other variables, for instance, parents' marital satisfaction and quality of marriage, and individuals' romantic styles. Relatedly, further research oriented toward investigating and recognizing mechanisms explaining this association is necessary. Fourth, the analysis of psychometric properties of scales used in the present study in regard to the test-rest reliability showed low reliability of the scales during a one-year interval. Therefore, the results obtained in the present study should be interpreted with caution, and future studies should be aimed at determining the test-retest reliability of the scales used in the present study. Finally, although the present study was conducted on a sample of Polish youth, it is possible to expand the generalizability of the results by carrying out further research of a cross-cultural nature, since cultural factors may influence the experience of love in different societies (Dion \& Dion, 1993) and affect the variability with which love is valued as a basis for marriage (Sorrell, 2005). Moreover, Poland is still a country of tradition- 
al values, where most adolescents and young adults desire to marry and have a successful marriage and family life (e.g., Rostowski, 2009). In addition, Polish culture is heavily influenced by the Roman Catholic religion, which affects social norms and attitudes concerning family formation, and the level of social disapproval of alternative marital and family forms (Baranowska-Rataj, Matysiak, \& Mynarska, 2013). Therefore, it is probable that these factors additionally influence marital and love attitudes. Despite these limitations, the present study highlights the importance of further research on the connection between different love attitudes, the love-marriage connection, and relationship status in young adulthood.

\section{FUNDING}

The study presented in the manuscript is financed by a grant from the National Science Centre in Poland as part of the research project "Marital, love and sex attitudes as predictors of relationship status in young adulthood - a longitudinal study" (UMO-2012/05/D/ HS6/03000).

\section{RefERENCES}

Acevedo, B. P., \& Aron, A. (2009). Does a long-term relationship kill romantic love? Review of General Psychology, 13, 59-65. https://doi.org/10.1037/a0014226

Adamczyk, K. (2019). The Polish versions of the Love Attitudes Scale and Marital Attitudes Scale. Mendeley Data, v1. https://doi.org/10.17632/j6nj7w2bfb.1\#file78b99be2-0c13-49a0-a028-b08dbfa2580e

Adamczyk, K., \& Hall, S. (2014). Exploring marital belief systems of single and partnered Polish young adults. In K. Adamczyk \& M. Wysota (Eds.), Functioning of young adults in a changing world (pp. 127143). Kraków: Wydawnictwo Libron - Filip Lohner.

Bakiera, L. (2009). Wartość małżeństwa w rozwoju człowieka dorosłego [The value of marriage in adult development]. In B. Harwas-Napierała (Ed.), Rodzina jako wartość w rozwoju człowieka [Family as a value in the human development] (pp. 25-57). Poznań: Wydawnictwo Naukowe UAM.

Baranowska-Rataj, A., Matysiak, A., \& Mynarska, M. (2013). Does lone motherhood decrease women's happiness? Evidence from qualitative and quantitative research. Journal of Happiness Studies, 15, 14571477. https://doi.org/10.1007/s10902-013-9486-z

Barry, C. M., Madsen, S. D., Nelson, L. J., Carroll, J. S., $\&$ Badger, S. (2009). Friendship and romantic relationship qualities in emerging adulthood: Differential associations with identity development and achieved adulthood criteria. Journal of Adult Development, 16, 209-222. https://doi.org/10.1007/ s10804-009-9067-x
Braaten, E. B., \& Rosén, L. A. (1998). Development and validation of the Marital Attitude Scale. Journal of Divorce \& Remarriage, 29, 83-91. https://doi. org/10.1300/J087v29n03_05

Baucom, D., \& Epstein, N. (1990). Cognitive-behavioral marital therapy. New York: Brunner/Mazel.

Borchet, J., Lewandowska-Walter, A., \& Rostowska, T. (2018). Performing developmental tasks in emerging adults with childhood parentification - insights from literature. Current Issues in Personality Psychology, 6, 242-251. https://doi.org/10.5114/cipp. 2018.75750

Brzezińska, A. I., Kaczan, R., Piotrowski, K., \& Rękosiewicz, M. (2011). Odroczona dorosłość: fakt czy artefakt? [Postponed adulthood: fact or artefact?]. Nauka, 4, 67-107.

Carroll, J. S., Badger, S., Willoughby, B. J., Nelson, L. J., Madsen, S. D., \& Barry, C. M. (2009). Ready or not? Criteria for marriage readiness among emerging adults. Journal of Adolescent Research, 24, 349375. https://doi.org/10.1177/0743558409334253

Carroll, J. S., Willoughby, B., Badger, S., Nelson, L. J., Barry, C. M., \& Madsen, S. D. (2007). So close, yet so far away: The impact of varying marital horizons on emerging adulthood. Journal of Adolescent Research, 22, 219-247. https://doi.org/10.1177/ 0743558407299697

Clarkberg, M., Stolzenberg, R. M., \& Waite, L. J. (1995). Attitudes, values, and entrance into cohabitational versus marital unions. Social Forces, 74, 609-632. https://doi.org/10.1093/sf/74.2.609

Cramer, K., Marcus, J., Pomerleau, C., \& Gillard, K. (2015). Gender invariance in the Love Attitudes Scale based on Lee's color theory of love. Testing, Psychometrics, Methodology in Applied Psychology, 22, 403-413. https://doi.org/10.4473/TPM22.3.6

Czernecka, J. (2008). Polski singiel: obraz w mediach a autowizerunek [The Polish single: image in the media and self-image]. In E. Malinowska (Ed.), Stereotypy a rzeczywistość [Stereotypes and reality] (pp. 110-137). Łódź: Oficyna Wydawnicza Tercja.

DePaulo, B., \& Morris, W. (2005). Singles in society and science. Psychological Inquiry, 16, 57-83. https://doi.org/10.1080/1047840X.2005.9682918

Dion, K. L., \& Dion, K. K. (1991). Psychological individualism and romantic love. Journal of Social Behavior and Personality, 6, 17-33.

Dion, K. L., \& Dion, K. K. (1993). Gender and ethnocultural comparisons in styles of love. Psychology of Women Quarterly, 17, 463-473. https://doi. org/10.1111/j.1471-6402.1993.tb00656.x

Donnelly, D., \& Burgess, E. (2008). The decision to remain in an involuntarily celibate relationship. Journal of Marriage and Family, 70, 519-535. https://doi. org/10.1111/j.1741-3737.2008.00498.x

Fitzpatrick, J., Blazek, M., Kazmierczak, M., Lewandowska-Walter, A., Pastwa-Wojciechowska, B., \& Blazek, W. (2013). Lifestyle and close relationship 
trends among young adults in Poland. Journal of Social and Personal Relationships, 31, 928-937. https://doi.org/10.1177/0265407513510478

Fowers, B. J., Lyons, E., Montel, K. H., \& Shaked, N. (2001). Positive illusions about marriage among married and single individuals. Journal of Family Psychology, 15, 95-109. https://doi.org/10.1037/08933200.15.1.95

Glenn, N. D., \& Kramer, K. B. (1987). The marriages and divorces of children of divorce. Journal of Marriage \& Family, 49, 811-825. https://doi.org/10.2307/ 351974

Goodboy, A. K., Myers, S. A., \& Members of Investigating Communication (2010). Relational quality indicators and love styles as predictors of negative relational maintenance behaviors in romantic relationships. Communication Reports, 23, 65-78. https://doi.org/10.1080/08934215.2010.511397

Hahn, J., \& Blass, T. (1997). Dating partner preferences: a function of similarity of love styles. Journal of Social Behavior and Personality, 12, 595-610.

Hall, S. S. (2006). Marital meaning exploring young adults' belief systems about marriage. Journal of Family Issues, 27, 1437-1458. https://doi.org/10. 1177/0192513X06290036

Hammock, G., \& Richardson, D. S. (2011). Love attitudes and relationship experience. The Journal of Social Psychology, 151, 608-624. https://doi.org/10. 1080/00224545.2010.522618

Hendrick, S. S., \& Hendrick, C. (1986). A theory and method of love. Journal of Personality and Social Psychology, 50, 392-402. https://doi.org/10.1037/00223514.50.2.392

Hendrick, C., \& Hendrick, S. (1995). Gender differences and similarities in sex and love. Personal Relationships, 2, 55-65. https://doi.org/10.1111/j. 1475-6811.1995.tb00077.x

Hendrick, C., Hendrick, S. S., \& Dicke, A. (1998). The Love Attitude Scale: Short Form. Journal of Social and Personal Relationships, 15, 147-159. https://doi. org/10.1177/0265407598152001

Hendrick, S. S., \& Hendrick, C. (2002). Linking romantic love with sex: Development of the Perception of Love and Sex Scale. Journal of Social and Personal Relationships, 19, 361-378. https://doi. org/10.1177/0265407502193004

Kaiser, Ch. R., \& Kashy, D. A. (2005). The contextual nature and function of singlism. Psychological Inquiry, 16, 122-126.

Kapusta, N. D., Jankowski, K. S., Wolf, V., Chéron-Le Guludec, M., Lopatka, M., Hammerer, C., Schnieder, A., Kealy, D., Ogrodniczuk, J. S., \& Blüml, V. (2018). Measuring the capacity to love: Development of the CTL-Inventory. Frontiers in Psychology, 9, 1115. https://doi.org/10.3389/fpsyg.2018.01115

Kephart, W. (1967). Some correlates of romantic love. Journal of Marriage and the Family, 29, 470-474. https://doi.org/10.2307/349585
Lee, J. A. (1973). The colors of love: an exploration of the ways of loving. Toronto: New Press.

Lehmann, V., Tuinman, M. A., Braeken, J., Vingerhoets, Ad. J. J. M., Sanderman, R., \& Hagedoorn, M. (2015). Satisfaction with relationship status: Development of a new scale and the role in predicting well-being. Journal of Happiness Studies, 16, 169184. https://doi.org/10.1007/s10902-014-9503-x

Levine, T. R., Strzyzewski-Aune, K., \& Park, H. S. (2006). Love styles and communication in relationships: Partner preferences, initiation, and intensification. Communication Quarterly, 54, 465-486. https://doi. org/10.1080/01463370601036515

Mandal, E., \& Latusek, A. (2018). Love attitudes, psychological femininity and masculinity, Machiavellianism, narcissism, and emotional intelligence of rejectors in close relationships. Current Issues in Personality Psychology, 6, 188-199. https://doi. org/10.5114/cipp.2018.75647

Medora, N. P., Larson, J. H., Hortaçsu, N., \& Dave, P. (2002). Perceived attitudes towards romanticism: A cross-cultural study of American, Asian-Indian, and Turkish young adults. Journal of Comparative Family Studies, 33, 155-178. https://doi.org/ 10.3138/jcfs.33.2.155

Murray, S. L., \& Holmes, J. G. (1997). A leap of faith? Positive illusions in romantic relationships. Personality and Social Psychology Bulletin, 23, 586604. https://doi.org/10.1177/0146167297236003

Ochnik, D., \& Mandal, E. (2016). Do Polish nevermarried singles feel stigmatized? In K. Adamczyk (Ed.), Singlehood from individual and social perspectives (pp. 163-191). Kraków: Wydawnictwo Libron - Filip Lohner.

Palus, K. (2010). Wybrane psychologiczne uwarunkowania braku partnera życiowego w okresie wczesnej dorostości [Selected psychological factors of the lack of a lifetime partner in young adulthood]. Poznań: Wydawnictwo Naukowe Wydziału Nauk Społecznych UAM.

Regan, P. C. (2008). General theories of love. In P. Regan (Ed.), The mating game: a primer on love, sex, and marriage (pp. 119-137). Thousand Oaks, CA: Sage Publications.

Rostowski, J. (2009). Współczesne przemiany rozumienia związku małżeńskiego [Contemporary changes in understanding marriage]. In T. Rostowska (Ed.), Psychologia rodziny. Matżeństwo i rodzina wobec wspótczesnych wyzwań [Psychology of family. Marriage and family towards contemporary challenges] (pp. 15-46). Warszawa: Wydawnictwo Difin.

Rydz, E. (2011). Important life decisions of young people. In E. Rzechowska, S. Steuden, D. Musiał, E. Rydz, \& M. Tatala (Eds.), Contemporary interpretations and applications of the theory of positive disintegration (pp. 25-43). Lublin: Towarzystwo Naukowe KUL. 
Sassler, S., \& Schoen, R. (1999). The effect of attitudes and economic activity of marriage. Journal of Marriage and the Family, 61, 147-159. https://doi.org/ $10.2307 / 353890$

Schachner, D. A., Shaver, P. R., \& Gillath, O. (2008). Attachment style and long-term singlehood. Personal Relationships, 15, 479-491. https://doi. org/10.1111/j.1475-6811.2008.00211.x

Shurts, W. M., \& Myers, J. E. (2008). An examination of liking, love styles, and wellness among emerging adults: Implications for social wellness and development. Adultspan Journal, 7, 51-68. https:// doi.org/10.1002/j.2161-0029.2008.tb00046.x

Simon, R. W., \& Barrett, A. E. (2010). Nonmarital romantic relationships and mental health in early adulthood: Does the association differ for women and men? Journal of Health and Social Behavior, 51, 168-182. https://doi.org/10.1177/0022146510372343

Simpson, J. A., Campbell, B., \& Berscheid, E. (1986). The association between romantic love and marriage: Kephart (1967) twice revisited. Personality and Social Psychology Bulletin, 12, 363-372. https:// doi.org/10.1177/0146167286123011

Sorrell, E. (2005). Romantic love and marriage: an analysis of the concept and functionality of romantic love as a marital stabilizing agent. Nebraska Anthropologist, 9, 16-25.

Spielmann, S. S., MacDonald, G., Maxwell, J. A., Joel, S., Peragine, D., Muise, A., \& Impett, E. A. (2013). Settling for less out of fear of being single. Journal of Personality and Social Psychology, 105, 1049-1073. https://doi.org/10.1037/a0034628

Sprecher, S., \& Toro-Morn, M. (2002). A study of men and women from different sides of the earth to determine if men are from Mars and women are from Venus in their beliefs about love and romantic relationships. Sex Roles, 46, 131-147. https://doi. org/10.1023/A:1019780801500

Such-Pyrgiel, M. (2014). The lifestyles of single people in Poland. Procedia - Social and Behavioral Sciences, 109, 198-204. https://doi.org/10.1016/j. sbspro.2013.12.444

Willoughby, B. J. (2014). Using marital attitudes in late adolescence to predict later union transitions. Youth \& Society, 46, 425-440. https://doi. org/10.1177/0044118X12436700

Willoughby, B. J., Hall, S. S., \& Luczak, H. P. (2013). Marital paradigms: a conceptual framework for marital attitudes, values, and beliefs. Journal of Family Issues, 36, 188-211. https://doi.org/10.1177/ $0192513 X 13487677$.

Willoughby, B. J., Medaris, M., James, S., \& Bartholomew, K. (2015). Changes in marital beliefs among emerging adults: Examining marital paradigms over time. Emerging Adulthood, 3, 219-228. https://doi.org/10.1177/2167696814563381.

Żurek, A. (2008). Single. Żyjąc w pojedynkę [Singles. Going it alone]. Poznań: Wydawnictwo UAM. 